\title{
A COMPARATIVE STUDY OF WATER MOVEMENT IN LEAF SCORCH DECLINE AFFECTED AND HEALTHY COCONUT PALMS USING LITHIUM AS A NON-RADIOACTIVE TRACER
}

\author{
W.S. Madurapperuma, H. Mendis, C.S. Ranasinghe, \\ N. Premasiri and M. Gunawardena \\ Coconut Research Institute, Lunuwila, Sri Lanka
}

\begin{abstract}
Obstructions to the movement of water, by physical blockages in the vascular system, are a possible cause of the Leaf Scorch Decline (LSD) disorder of coconut palms. This hypothesis was tested by comparing the pattern of water movement in healthy and LSD-affected coconut palms, using Lithium, a non-radioactive tracer, as an indicator. Pattern of water transport in the leaf canopy of healthy and LSD-affected palms was similar but the quantities transported were different. Less water movement in moderate-LSD palms than in healthy and mild-LSD palms suggest the development of obstructions to water movement when the disorder increases in severity. Uptake of water into the root system was not affected by the LSD disorder. However, in moderate-LSD palms more water was retained in the roots than in healthy and mild-LSD palms. This also points to restrictions to water movement in the moderate-LSD palms. The relatively high amounts of Li retained in the roots of healthy and mild-LSD palms need further investigation.
\end{abstract}

Key words: Leaf Scorch Decline, visible symptoms, pattern of water movement, non-radioactive tracer

\section{INTRODUCTION}

The characteristic visible symptom of the Leaf Scorch Decline (LSD) disorder is leaf scorch that starts from the tips of the leaflets and advances towards the midrib of the frond (Davis, 1962; Ekanayake, 1964, Rajapaksha and Fernando, 1995; Madurapperuma et al, 2004; Ranasinghe, 2005). Scorch first appears on the physiologically less active mature fronds (mild stage of LSD), and advances progressively to the younger fronds of the middle whorl of the canopy (moderate LSD) and to still younger fronds (severe stage). The other symptoms that develop progressively in moderately and severely affected palms are: a reduction in the length of newly emerging fronds; number and size of inflorescences; nut set and yield; and bearing abnormally 
elongated nuts, and tapering of the trunk (Peries, 1968; Rajapaksha and Fernando, 1995; Madurapperuma et al., 2004; Ranasinghe, 2005).

Physiological studies with LSD-affected coconut palms have demonstrated a significant reduction in the transpiration rate, photosynthesis and leaf water potential (LWP); and an increase in leaf stomatal resistance and ABA concentration in the xylem sap, in comparison to healthy palms (Jayasekara et al., 1989; Ranasinghe, 2005). This suggests that LSD-affected palms are water stressed. Even with the soil moisture level at field capacity (FC), the LWP of LSD-affected palms was lower than in healthy palms (Jayasekara et al., 1989), which points to an internal water deficit condition in LSD palms. This condition could be attributed to either poor water absorption due to a paucity of live roots in LSD-affected palms (Jayasekara and Premasiri, 1986; Mahindapala and Chandrasena, 1975; Ranasinghe et al., 2002), or physical blockages in the water transport tissues.

Physical barriers in the vascular system limiting the movement of water to plant tissues will also restrict the supply of nutrients to these tissues and retard growth. Nutrients absorbed by the roots are moved upwards with the transpiration stream. Hence the efficiency of nutrient uptake will depend on the physiological status of plants (Vidanaarachchi and Nor, 1994).

Clearly, in plants under physiological stress the uptake of water and nutrients is inevitably reduced. Generally, when the stress factors are removed the plants recover. However, LSD-affected coconut palms suffer from water stress even under optimum environmental conditions. It may, therefore, be assumed that physical blockages in the vascular system are involved. The foregoing leads to the hypothesis: water movement from roots through the trunk to the crown of LSD-affected palms is restricted by physical blockages in the vascular system. This study aims to test the hypothesis, and identify the zones where restrictions occur, using Lithium as a non-radioactive tracer.

\section{MATERIALS AND METHODS}

$\mathrm{Li}$, a non-radioactive tracer, was used to study the water transport pattern in LSD-affected coconut palms. The advantages of $\mathrm{Li}$ are its low cost, availability of simple analytical methods, and that it is measurable at very low concentrations ( 0.01 or even lesser). Moreover, Li occurs naturally in soils at very low concentrations, and when added to the soil it is taken up freely into the shoot system (Martin et al., 1982). Hence, the concentration of $\mathrm{Li}$ in different plant tissues, after application of $\mathrm{Li}$, will be a measure of the 
amount of $\mathrm{Li}$ as well as the amount of water that has moved into different tissues (Ranasinghe and Wijerathne, 2005).

The experiment was conducted at Poththukuluma Research Station in the agro climatic region IL3. Thirty-year-old coconut palms, of the Tall variety (var. typica), uniformly managed as per recommendations of the Coconut Research Institute were selected for the study. Six palms each with mildLSD and moderate-LSD (as described in Ranasinghe, 2005) and apparently healthy palms were selected for the experiment. Palms that had advanced beyond the moderate stage of LSD were not selected for this study as their response to treatments was poor (unpublished data). A Randomized Complete Block Design with six replicates per treatment was used for the experiment.

A sunny day (light intensity between $1200-1500 \mu \mathrm{mol} \mathrm{m} \mathrm{m}^{-2}$ ) was selected for root feeding. A $100 \mathrm{ml}$ of $1 \% \mathrm{LiCl}$ solution was prepared for root feeding of palms. A mature, brown coloured, active root, growing at an angle of about $60^{\circ}$ from the soil surface, was selected and prepared for root feeding. Only one root was selected for root feeding per palm assuming that all active roots were functioning equally well, and that a single active root is a representative sample. The root was severed with a smooth sharp cut and the cut end covered with moist cotton wool to prevent the entry of air bubbles. Immediately thereafter the root was inserted into a $1 \%$ solution of $\mathrm{LiCl}$, contained in a polythene bag. The polythene bag with the $\mathrm{LiCl}$ solution was tightly tied to the root in a manner that ensures the cut end is always immersed in the solution, even when the solution level falls due to uptake.

Three days after root feeding, leaf, nut and root sampling was carried out. Root samples were collected from the fed roots, and from untreated roots on the opposite side to determine lateral movement within the root system. The amount of $\mathrm{LiCl}$ taken up by roots was calculated by measuring the amount left in the bags. Leaf samples were taken from the $3^{\text {rd }}, 6^{\text {th }}, 9^{\text {th }}, 14^{\text {th }}, 18^{\text {th }}$ and $22^{\text {nd }}$ fronds, and nuts were taken from the $5^{\text {th }}, 8^{\text {th }}$ and $12^{\text {th }}$ bunches. Water of the harvested nuts was filtered using Whatman 42 filter paper, frozen at -20 ${ }^{\circ} \mathrm{C}$ and stored until the $\mathrm{Li}$ concentration was determined. Leaflets, without the mid rib, husks, cut into small pieces, and the root samples were dried at $80^{\circ} \mathrm{C}$ for three days and powdered using a Cyclotec (1093) plant sample grinder with $1 \mathrm{~mm}$ size sieve. 


\section{Determination of $\mathbf{L i}$}

Ten milliliters of defrosted nut water was used to determine $\mathrm{Li}$ in the nut water. For the analysis of $\mathrm{Li}$ in leaf, husk and roots, $1 \mathrm{~g}$ each of the powdered sample was used. Samples were measured into $250 \mathrm{ml}$ conical flasks, and after adding $20 \mathrm{ml}$ of deionized water they were shaken for two hours and filtered using Whatman 42 filter paper. Li content in the filtrate and in defrosted nut water was determined (Ranasinghe and Wijerathene, 2005) using an Atomic Absorption Spectrophotometer (Shimadzu AA-6200, Japan). The $\mathrm{Li}$ concentration in a particular organ indicates the amount of $\mathrm{Li}$ that has moved into it, along with water, from the treated root.

\section{Analysis of Data}

Data was analysed by ANOVA, using the GLM procedure of SAS.

\section{RESULTS}

\section{Determination of Li in Roots}

In healthy, mild-LSD and moderate-LSD palms, the Li concentration in treated roots $(10-13 \mu \mathrm{g} / \mathrm{g})$ was significantly higher than in untreated roots (0.05-0.2 $\mu \mathrm{g} / \mathrm{g})$. The high $\mathrm{Li}$ concentration in the treated roots of both healthy and LSD palms indicates that the uptake of water is not obstructed when it is supplied directly to the roots. However, the low concentration of $\mathrm{Li}$ in untreated roots shows that the lateral movement of water within the root system is restricted. In untreated roots, the highest concentration of $\mathrm{Li}$ was observed in mild-LSD palms $(0.2 \mu \mathrm{g} / \mathrm{g})$ while the lowest concentration in moderate-LSD palms $(0.05 \mu \mathrm{g} / \mathrm{g})$, whereas in the treated roots, the highest $\mathrm{Li}$ concentration was in moderate-LSD palms $(12.56 \mu \mathrm{g} / \mathrm{g})$, with appreciable concentrations in the mild-LSD $(8.1 \mu \mathrm{g} / \mathrm{g})$ and healthy palms $(8.7 \mu \mathrm{g} / \mathrm{g})($ Fig $1)$. 
Treated

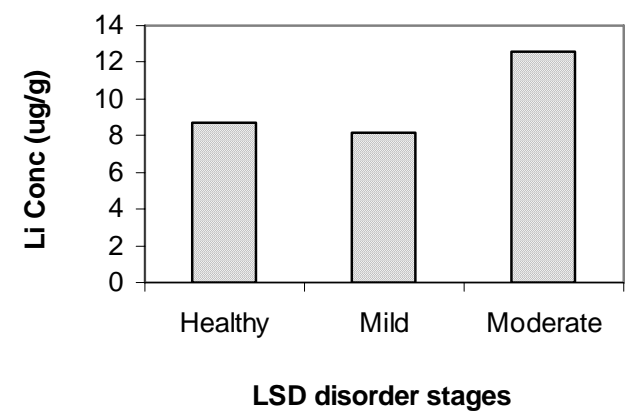

Untreated

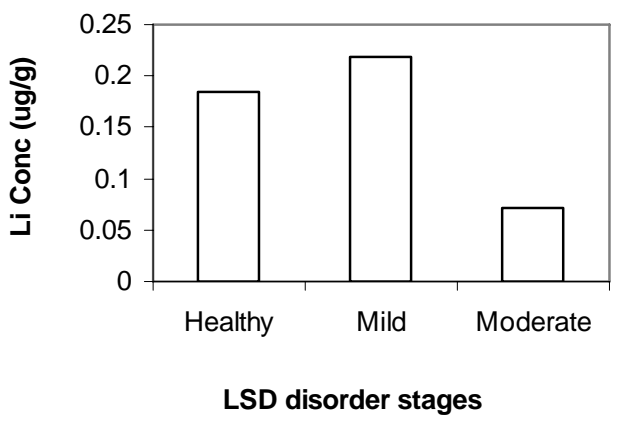

Figure 1. : Li concentration in treated roots (1a) and untreated roots (1b) in healthy, mild-LSD and moderate-LSD palms, after root feeding with $1 \% \mathrm{LiCl}$.

\section{Determination of $\mathrm{Li}$ in nut water and husk}

Li content in the nut water and husk of healthy and LSD affected palms, was not significantly different in any of the maturity stages tested (5, 8 and 12 months old nuts). The pattern of Li transport to nuts in healthy and LSD palms was similar, with the highest Li concentration of $0.03 \mu \mathrm{g} / \mathrm{g}$ in the nut water of 5 month tender nuts), declining to $0.018-0.02 \mu \mathrm{g} / \mathrm{g}$ in the 8 and 12 month nuts (Figure 2a). The inverse pattern was observed in the husk, with the lowest concentration of $\mathrm{Li}(0.015 \mu \mathrm{g} / \mathrm{g})$ in the husk of 5 month nuts gradually increasing to $0.03 \mu \mathrm{g} / \mathrm{g}$ in 12 month nuts (Figure 2b). 
2a.

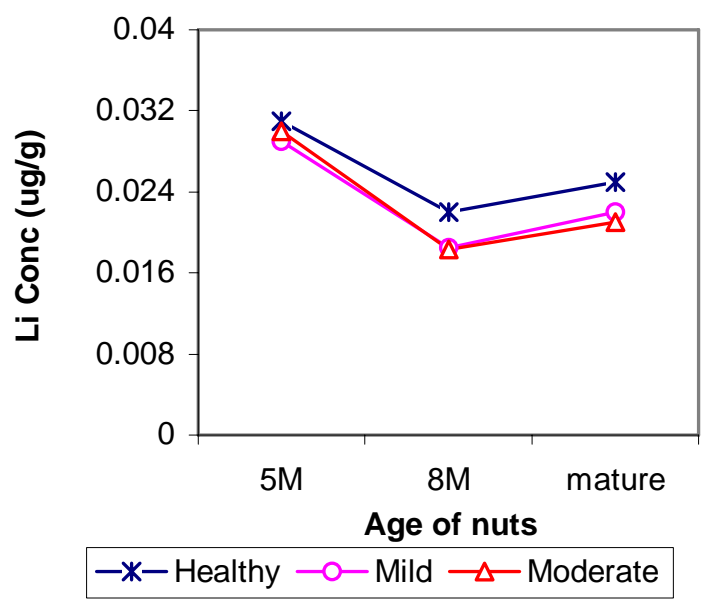

$2 b$.

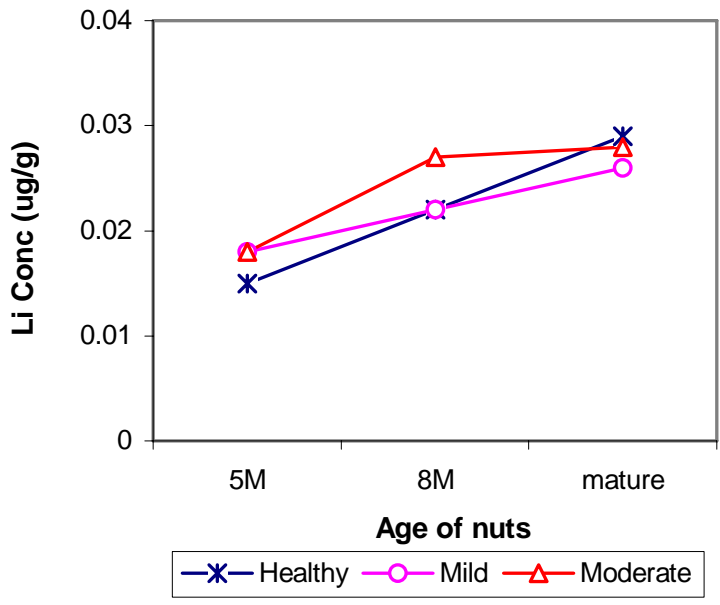

Figure 2: Li concentration in the nut water (2a) and husk (2b) of nuts of different age $(5 \mathrm{M}=5$ months, $8 \mathrm{M}=8$ months and mature $=12$ months), in healthy, mild-LSD and moderate-LSD palms, after root feeding with $1 \% \mathrm{LiCl}$

\section{Determination of $\mathrm{Li}$ in leaves}

The Li content in the leaves of healthy and LSD-affected palms, was not significantly different in any of the fronds tested $\left(3^{\text {rd }}, 6^{\text {th }}, 9^{\text {th }}, 14^{\text {th }}, 18^{\text {th }}\right.$ and $22^{\text {nd }}$ fronds). The pattern of Li movement, and hence water movement to the fronds, was similar in healthy and LSD palms: a gradual increase up to the $14^{\text {th }}$ frond and declining thereafter. In all the fronds tested, the lowest concentration of $\mathrm{Li}$ in all ages of fronds was in the moderate-LSD palms while the highest concentration was in the mild-LSD palms, an interesting feature that merits further investigation (Figure 3). 


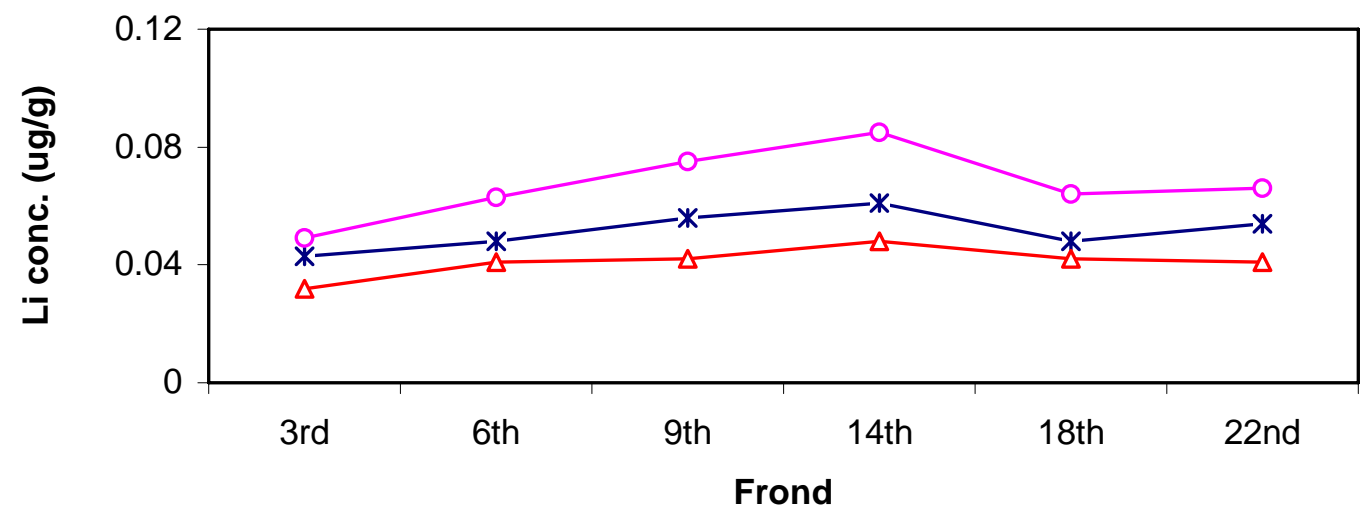

$-*-$ Healthy $\multimap-$ mild $\rightarrow-$ moderate

Figure 3: Li concentration in fronds of different maturity, in healthy, mildLSD and moderate-LSD palms, after root feeding with $1 \% \mathrm{LiCl}$

\section{DISCUSSION}

The gradual increase of $\mathrm{Li}$ concentration up to $14^{\text {th }}$ frond and decline thereafter shows that the pattern of water transport in leaves, as measured by $\mathrm{Li}$ concentration, is in keeping with their physiological maturity. The demand for water of the younger fronds in the canopy is greater as they are physiologically more active than the mature fronds. This pattern of water transport was common to healthy, mild-LSD and moderate-LSD palms, showing that the demand of individual fronds has a greater bearing than the LSD status of the palms. However, in terms of the quantity of water transported, the leaf $\mathrm{Li}$ concentration, in all the fronds tested, was consistently lower in the moderate-LSD palms than in healthy and mild-LSD palms. This is suggestive of obstructions to water movement in moderateLSD palms. It appears that while there are no obstructions to water movement in mild-LSD palms, restrictions to water transportation could develop as the disorder condition increases in severity.

LI analysis shows that water movement into nut water behaves in a similar manner to that of fronds. The Li concentration in nut water is at a peak in the 5 month tender nuts and decreases in the nuts of the more mature bunch indicating a greater movement of water to the tender nuts. Li concentrations in the water of 5 month tender nuts were nearly identical in healthy, mildLSD and moderate-LSD palms which indicates that water transport into the 5 month nuts was not affected by the disorder. However, the somewhat higher 
$\mathrm{Li}$ concentrations in the water of more mature nuts of healthy palms than in LSD-affected palms suggests that water movement into the nut water of LSD palms is restricted.

The very high Li concentration in treated roots compared to untreated roots shows that lateral movement of water within the root system is limited. In the untreated roots, Li concentration was relatively high in healthy and mildLSD palms, and low in moderate-LSD palms, which suggests that while water movement is not affected in healthy and mild-LSD palms it is restricted in moderate-LSD palms. The accumulation of $\mathrm{Li}$ in the treated roots of moderate-LSD palms also supports this contention.

The results of this study show that the uptake of water by the roots, and the pattern of water movement from the root system to crown tissues are not affected by the LSD disorder. However, the quantum of water moved up to the fronds is restricted in moderate-LSD palms possibly due to the presence of obstructions. Restrictions in the root system may at least partially account for the reduced water movement to the crown tissues in moderate-LSD palms. Water movement in mild-LSD palms is free of restrictions. The higher stomatal diffusive resistance in moderate and severe LSD palms and the increasing internal water deficit with the increasing severity of the LSD disorder, observed by Ranasinghe, 2005, support the present findings. Further studies on water transport patterns at different heights along the trunk would provide interesting information.

As Li is not a plant nutrient, plant tissues are not a sink for Li. Therefore, higher levels of $\mathrm{Li}$ in the tissues indicate that a greater amount of water has moved into the plant parts. Although the Li concentration in roots of healthy and mild-LSD palms, in this study was less than of moderate-LSD palms, it was still a considerably high level. In a similar experiment to study the water transport pattern in palms affected by Coconut Rapid Decline, the $\mathrm{Li}$ detected was very much lower in the healthy roots, and higher in the canopy level tissues than in the present study (Ranasinghe and Wijerathene, 2005). These differences indicate the need for more investigations on the fate of $\mathrm{Li}$ in plant tissues and use of $\mathrm{Li}$ in water transport studies in LSD-affected palms, including the reasons for retaining large amounts of $\mathrm{Li}$ in roots of healthy and mild-LSD palms. 


\section{CONCLUSION}

Studies using $\mathrm{Li}$ as a tracer show that uptake of water into coconut roots, and the pattern of water movement from the roots to the crown tissues, are not influenced by the LSD disorder. However, in moderate-LSD palms water is retained in the roots, and the movement of water to the crown level is restricted.

\section{ACKNOWLEDGEMENT}

The financial assistance received from the Council for Agricultural Research Policy (Grant No. 12/537/408) is gratefully acknowledged.

\section{REFERENCES}

Davis, T.A. (1962). Coconut Withering Disease of Ceylon. Coconut Research Institute of Sri Lanka Bulletin, No.22. Lunuwila, Sri Lanka.

Ekanayake, U.B.M. (1964). Annual Report of the Crop Protection Division, Coconut Research Institute of Sri Lanka (1963). Ceylon Cocon. Quart. 15, pp 50-57.

Fox, R.L. and Lipps, R.C. (1964). A comparision of stable strontium and 32P as tracers for estimating alfalfa root activity. Plant and Soil, 20, 337350 .

Jayasekara, C. and Premasiri, R.D.N. (1989). Report of the Plant Physiology Division. Annual Report of the Coconut Research Institute, Sri Lanka, 175-179.

Lipps, R.C. Fox, R.L. and Kochier, F.E. (1957). Characterizing root activity of alfalfa by radioactive tracer techniques. Soil Sci. 84: 195-204.

Madurapperuma, W.S., Ranasinghe, C.S., Mendis, H., Premasiri, N., Seram, A., Gunawardena, M., (1994). Application methods of Zn and the effect of macro and micro nutrient applications on the expression of leaf scorch decline symptoms in coconut (Cocos nucifera L) In: Proceedings II; International conference, $75^{\text {th }}$ Anniversary, Coconut Research Institute of Sri Lanka. 237-247 pp. 
Mahindapala, R. and Chandrasena, A.M. (1975). Yield and drupe characteristics of coconut palms affected with Leaf Scorch Decline. Ceylon Coconut Quarterly 26:73-76.

Martin, M.P.L.D. Snaydon, R.W. and Drennan, D.S.H. (1982). Lithium as a non-radioactive tracer for roots of intercropped species. Plant and Soil. 64, 203-208.

Nethsinghe, D.A. (1966). The application of isotopes in fertilizer research on the coconut palm. Ceylon Coconut Quart. 17:61-72.

Peries, O.S. (1968). Studies on Leaf Scorch Decline of coconut palms. Ceylon Coconut Quarterly 3: 109-115.

Rajapaksha, C.N.K. and Fernando, L.C.P. (1995). Leaf Scorch Decline of coconut in Sri Lanka in Proceedings on International Workshop on Lethal Yellowing-like Diseases of Coconut, Ghana 5-9 November 1995., 97-104.

Ranasinghe C.S. and Wijerathene, A.J. (2005). Vegetative, reproductive and physiological changes in coconut palms affected by Coconut Rapid Decline. Cocos 17, 01-10.

Ranasinghe, C.S. (2005). Changes in the physiological performance of Leaf Scorch Decline (LSD) affected coconut (Cocos nucifera) palms. Experimental Agriculture 41, 255-265.

Ranasinghe, C.S., Wijesekara, R. and Wimalasekara,R. (2002). Rapid Decline Syndrome of Coconut (Cocos nucifera L.) - Preliminary report of a new condition. Palms 46:167-171.

Vidanaarachchi, L and Nor, Y.M. (1994). Influence of palm oil sludge on physical properties of soil and growth characterization of oil palm seedling “Elaeis guineensis), Trop. Agric. (Trinidad) Vol. 71, No 2: 95-99. 